\title{
Light absorption efficiency and the package effect in the leaves of the seagrass Thalassia testudinum
}

\author{
Susana Enríquez ${ }^{*}$ \\ Unidad Académica Puerto Morelos, Instituto de Ciencias del Mar y Limnología, Universidad Nacional Autónoma de México,
} (ICML-UNAM), Apdo. Postal 1152, 77500 Cancún, Mexico

\begin{abstract}
In this study, I evaluate the variability in light absorption efficiency of Thalassia testudinum leaves and the magnitude of the package effect affecting seagrass leaves. The large variability observed in pigment density and leaf absorptance of $T$. testudinum leaf segments, was compared to the variation in light absorption efficiency reported for leaves of Mentha aquatica, a species that maintains a specialized bifacial mesophyll and has 3 times higher leaf pigment content. Pigment light absorption efficiency of $T$. testudinum leaves was also compared to the interspecific variability reported for leaf sections of 12 seagrass species collected in 10 tropical (Mexican Caribbean and Philippine Indo-Pacific) and 31 temperate (Spanish Mediterranean, Portuguese Atlantic and Danish fjørds) coastal areas. The results of this comparison confirmed that $T$. testudinum leaves are affected by the package effect, because pigment light absorption efficiency decreases non-linearly as pigment content per unit area increases. The finding that $M$. aquatica leaves have a 1.5 times higher pigment light absorption efficiency than $T$. testudinum leaves for similar pigment content, does not necessarily indicate that the specialized leaf anatomy developed by seagrasses (i.e. a pigmented epidermis and an unpigmented leaf mesophyll) has led to a reduction in light absorption efficiency. This is because temperate seagrass leaves, which have a 2.5 times higher chlorophyll content than flatshaped leaves of tropical species, exhibit a 1.4 times higher efficiency than M. aquatica leaves of similar pigment density. The possible effect of leaf morphology (i.e. leaf thickness and the specific leaf area) on the variation of leaf absorptance of $T$. testudinum was finally addressed to clarify the capacity of seagrass leaf morphology in counterbalancing pigment self-shading within the thin epidermis.
\end{abstract}

KEY WORDS: Seagrasses - Light absorption - Absorptance - Specific absorption - Package effect · Photoacclimation $\cdot$ Leaf thickness $\cdot$ Specific leaf area $\cdot$ Thalassia testudinum

\section{INTRODUCTION}

Seagrasses are aquatic monocotyledons confined to the marine environment (Kuo \& Den Hartog 2000). Their ancestors were terrestrial plants which recolonized marine coastal areas between 90 to 120 million years ago (Den Hartog 1970). Although many land plants have successfully re-colonized freshwater environments (Sculthorpe 1967), seagrasses are unique in having re-colonized the sea. Four functional properties are considered indispensable for a marine plant (Arber 1920, Kuo \& Den Hartog 2000): (1) to be able to grow fully submerged, (2) to have an efficient anchoring system, (3) to be able to osmoregulate and (4) to have a hydrophilous pollination mechanism. Kuo \& Den Hartog (2000) remarked that seagrasses obviously fulfill these requirements; however, these 4 properties alone are not sufficient to define a marine plant, as several taxa of aquatic plants also satisfy these 4 criteria (i.e. species within the genera Ruppia, Zannichellia, Potamogeton and Najas), although they do not normally occur in marine habitats. Kuo \& Den Hartog (2000), however, pointed out a fifth property: seagrasses are able to successfully compete with other organisms in 
the marine environment. Understanding the ecological success of seagrasses in the marine environment still needs to be clarified at many different levels of plant complexity, from the description of physiological mechanisms to the study of their competitive ability in relation to other marine primary producers. The analysis of the competitive ability of seagrasses requires the description of 2 basic functional properties: (1) the ability to collect light, and (2) the efficiency in the use of the light absorbed to support plant growth.

Seagrass leaves, as is the case in other hydrophytes, have evolved specific adaptations to submerged conditions. They have lost stomata (Tomlinson 1982), but have developed aerenchyma and a thin cuticle that facilitates the exchange of gas and solute with the surrounding water. They have also developed a photosynthetic epidermis losing the specialized mesophyll characteristic of bifacial land leaves (e.g. parenchyma and a spongy mesophyll). Most of the leaf pigment is concentrated into a single epidermal cell layer, which represents less than $20 \%$ of the leaf volume (Tomlinson 1980). The internal mesophyll tissue is unpigmented and formed by cells that contain large vacuoles. The role of the unpigmented mesophyll cells is not fully understood, but has been related to the maintenance of an internal gas flow within the lacunar system (Larkum et al. 1989), and to the maintenance of leaf turgor under variations in seawater salinity (Tyerman 1989). The concentration of all photosynthetic activity into the leaf epidermis may have contributed to the evolutionary success of seagrasses, because photosynthesis has easier access to bicarbonate, the main source of inorganic carbon in seawater (Larkum et al. 1989). Nevertheless, the unpigmented nature of the mesophyll cells surrounding the leaf lacunar system is not fully understood, and neither are its consequences for the optical properties of seagrass leaves.

Few studies have described the light absorption properties of seagrass leaves (Enríquez et al. 1992, 1994, Major \& Dunton 2000, 2002, Cummings \& Zimmerman 2003). The variation in pigment light absorption efficiency has been examined in 12 seagrass species (Enríquez et al. 1992, 1994), as well as in a tropical (Thalassia testudinum) and in a temperate (Zostera marina) species (Cummings \& Zimmerman 2003). Two comparisons concluded that seagrass leaves are affected by the package effect based on: (1) the 1.4-fold increment found in leaf absorptance (i.e. the fraction or percentage of incident light absorbed, sensu Kirk 1994) in Posidonia oceanica leaves despite an almost 6 -fold increment observed in chlorophyll a content per unit area (9.4-fold variation in chlorophyll $a$ content per unit of leaf dry weight, Enríquez et al. 1992); and (2) the $9 \%$ increment found comparing leaves of $T$. testudinum and $Z$. marina despite the 5-fold increment observed in total leaf chlorophyll content per unit of fresh weight (Cummings \& Zimmerman 2003). The package effect refers to the reduction in light absorption efficiency experienced by photosynthetic pigments due to pigment self-shading, when pigments are arrayed in live structures such as pigment-protein complexes, piled thylakoids, chloroplasts, cells and colonies or tissues (Duysens 1956, Kirk 1975a,b, 1976, 1994, Morel \& Bricaud 1981). The chlorophyll $a$-specific absorption coefficient (i.e. the absorption coefficient normalized to pigment content, sensu Geider \& Osborne 1992, Kirk 1994) has been used as a descriptor of the intra- and inter-specific variation in pigment light absorption efficiency, not only for phytoplankton populations but also for hermatypic corals (Dubinsky et al. 1984, 1990, Wyman et al. 1987, Lesser et al. 2000) and for leaves of higher plants (Enríquez \& Sand-Jensen 2003). The package effect has, therefore, been described as the non-linear reduction in pigment light absorption efficiency as cell or colony size increases (Kirk 1976), or pigment per unit of projected area increases (Morel \& Bricaud 1986, Haardte \& Maske 1987, Osborne \& Geider 1989, Enríquez \& Sand-Jensen 2003). Cummings \& Zimmerman (2003) have supplied the first estimations of the specific-absorption coefficient for seagrass leaves; however, no description of the pattern of variation as a function of chlorophyll density has yet been provided.

Recently, the assessment of leaf optical properties of Mentha aquatica L. (Enríquez \& Sand-Jensen 2003) has used the specific-absorption coefficient to examine pigment absorption efficiency as a function of pigment content and leaf morphology. M. aquatica is an amphibious freshwater species whose leaves have the specialized bifacial mesophyll of a terrestrial leaf. The mesophyll of $M$. aquatica is formed by a single palisade cell layer and 3 layers of spongy mesophyll cells. Enríquez \& Sand-Jensen (2003) found a strong negative association between the specific absorption coefficients (for the PAR range and for the chlorophyll $a$ peak at $680 \mathrm{~nm}$ ) and chlorophyll density, and concluded that leaves of $M$. aquatica are affected by the package effect, despite their ability to increase photon path length through multiple scattering within the tissue (factor of light absorption intensification $\beta>1$, sensu Rühle \& Wild 1979).

Despite this progress on intact multicellular structures, the ability of seagrass leaves to improve light absorption efficiency through multiple scattering, thus counterbalancing the package effect, has not been examined fully. In this study, I determine the significance of the package effect and its consequences on light harvesting efficiency in the leaves of Thalassia testudinum, and then compare that with the values estimated for Mentha aquatica and for 11 seagrass spe- 
cies (Cymodocea nodosa, Enhalus acoroides, Halodule uninervis, H. wrightii, Halophila ovalis, Posidonia oceanica, Syringodium isoetifolium, S. filiforme, Thalassia hemprichii, Zostera marina and Z. noltii). The aim of this comparison is to contribute to the understanding of the evolutionary success of seagrasses by assessing the efficiency with which their leaves absorb light. The objectives are to (1) examine the variability of the specific absorption coefficient as a function of chlorophyll density, (2) compare estimates of specific absorption in $T$. testudinum with those of $M$. aquatica (a species that exhibits typical terrestrial leaf morphology), and finally (3) examine species-specific differences associated with light harvesting abilities among 12 seagrass species collected in 10 tropical (Mexican Caribbean and Philippine Indo-Pacific) and 31 temperate (Spanish Mediterranean, Portuguese Atlantic and Danish fjørds) coastal areas.

\section{MATERIALS AND METHODS}

The optical properties of Thalassia testudinum leaves were examined by spectroscopic determinations of 307 leaf sections. T. testudinum leaves were collected in the Puerto Morelos reef-lagoon (Mexican Caribbean, Cancun) from 7 different meadows, differing in their proximity to the shoreline or to the fringing reef. The meadows also differ in leaf biomass density displayed above the sediment $(\mathrm{CV}=50.3 \%)$ as a result of changes in shoot size (biomass basis, $\mathrm{CV}=55.8 \%$ ) and shoot density $(\mathrm{CV}=47.6 \%)$. Four replicates of the second youngest leaf of the shoot, per meadow, were examined every $2 \mathrm{~cm}$. Given that leaves differed in length $(13.5$ to $41 \mathrm{~cm})$, leaves were cut into 6 to 20 segments. Light absorption was measured using the opal glass technique developed for intact plant leaves by Shibata (1959). Fragments of leaves were mounted into $3 \mathrm{ml}$ cuvettes filled with filtered seawater. Leaf sections were held against the wall of the cuvette with a holder specifically developed to avoid leaf misplacement during the spectroscopic determinations. Light absorption was measured at $1 \mathrm{~nm}$ intervals between 380 and $750 \mathrm{~nm}$ in an Aminco DW2 (USA) spectrophotometer controlled by an OLIS (USA) data collection system (Fig. 1a). Bleached leaves were used as a reference to correct for non-pigment absorption. Leaves were submerged for $24 \mathrm{~h}$ in filtered seawater, diluted with $1 \%$ bleach (vol:vol), to extract all photosynthetic pigments. Two descriptors were used: (1) average light absorption for the range between 400 and $700 \mathrm{~nm}$ (PAR range), and (2) light absorption at $680 \mathrm{~nm}$, which is the red peak of the chlorophyll $a$, where there is minimal interference from accessory pigments. The attenuance values (apparent absorbance) obtained were corrected
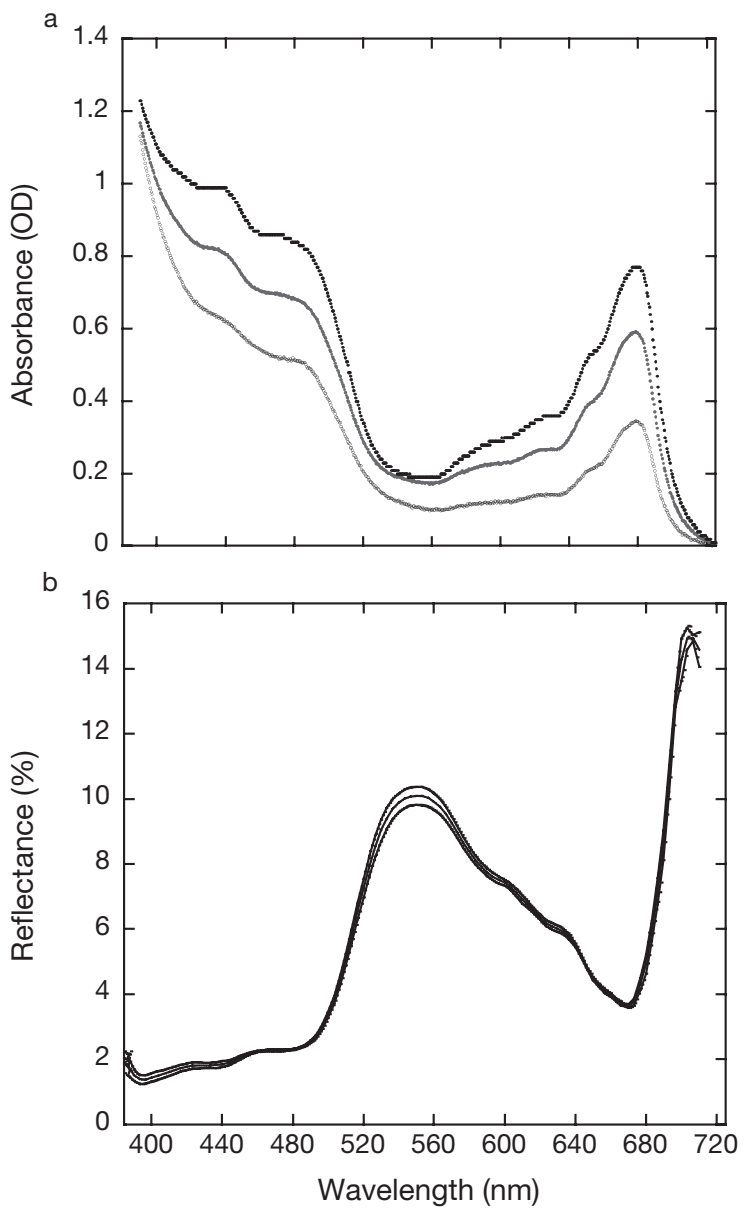

Fig. 1. Thalassia testudinum. (a) Absorbance (OD) spectra of 3 leaf sections with $2.3,8.7$ and $26 \mu \mathrm{g} \mathrm{chl}(a+b) \mathrm{cm}^{-2}$; (b) average reflectance spectrum \pm SE of 6 leaf sections

to exclude residual scattering by subtracting absorbance at $725 \mathrm{~nm}$. This spectroscopic technique may overestimate absorptance if residual- and back-scattering are significant. In this study, absorbance at $725 \mathrm{~nm}$ was low in all cases, confirming low levels of back- and residual-scattering. Nevertheless, reflectance spectra of $T$. testudinum leaves were measured in the PAR range using a SpectraPro 300i spectrometer (Acton Research) attached to a miniature fiberoptic (Fig. 1b). Leaf reflectance of $T$. testudinum leaves was low, confirming the appropriateness of Shibata's technique for seagrasses, as was the variability found among leaves $(5.5 \% \pm 0.097$ on average for the PAR range (400 to $700 \mathrm{~nm}$ ), and $4.9 \% \pm 0.29$ at the chlorophyll a peak at $680 \mathrm{~nm}, x \pm \mathrm{SE}, \mathrm{n}=6$ ).

Light absorption is expressed as absorptance (i.e. fraction of light absorbed) calculated from measurements of absorbance (i.e. optical density, OD) using the equation: Absorptance $=1-10^{\text {-absorbance }}$. Absorptance values were further corrected by subtracting (1) leaf reflectance for the PAR average or (2) leaf reflectance 
at $680 \mathrm{~nm}$. Specific absorption was estimated using the exponent in the exponential function $[\exp =-\ln (1-$ absorptance)], and this value was normalized to pigment content.

Pigment concentration was measured spectophotometrically on a subsample of the same fragments used for light absorption measurements, following pigment extraction of a homogenized suspension in $80 \%$ acetone (Dennison 1990). Total carotenoids and chlorophyll $a$ and $b$ of leaf extracts were calculated using the equations of Lichtenthaler \& Wellburn (1983).

The inter-specific comparison was performed using values reported in the literature (Enríquez et al. 1992, 2002, 2004, Olesen et al. 2002) for 4 temperate Mediterranean seagrasses: Posidonia oceanica, Cymodocea nodosa, Zostera noltii, Z. marina; and 6 tropical seagrass species from the Mexican Caribbean: Thalassia testudinum, Halodule wrightii, and the Philippines: Enhalus acoroides, Thalassia hemprichii, Halodule uninervis, Halophila ovalis together with average estimations for Syringodium filiforme and S. isoetifolium (S. Enríquez unpubl. data). Samples were collected from 41 different sites: Spanish Mediterranean (22), Portuguese Atlantic (6), Danish fjørds (3), Mexican Caribbean (10) and the Philippine Indo-Pacific (1). These sites encompassed: (1) spatial variability (Enríquez et al. 1992), (2) photoacclimatory depth (Olesen et al. 2002) and canopy responses (Enríquez et al. 2002), and (3) annual variability (Enríquez et al. 2004).

For the statistical analyses, Pearson correlation coefficients (r) were used to describe the association between different leaf descriptors. Least-squares (LS) regression analyses of non-transformed or, if required, log-log transformed data (according to the function: $\log Y=a+$ $b \log X$, which describes the allometric function $Y=a X^{b}$ ) were also used. To estimate the scaling exponent $\left(b^{\prime}\right)$, model II regression analysis (reduced major axis [RMA]; Niklas 1994) was used. Data were analyzed using a single-factor ANOVA for comparison among sites.

\section{RESULTS}

Total chlorophyll $(a+b)$ density varied 1 order of magnitude, from a minimum value of 19.6 to a maximum value of $267.7 \mathrm{mg} \mathrm{chl} \mathrm{m}^{-2}$ (Table 1). As a result of the large variability observed within sites (coefficient of variation ranged from 33.9 to $62.8 \%$ among sites), no significant variation in total leaf chlorophyll density was observed among sites (ANOVA, p > 0.05). Variation in leaf absorptance was considerably smaller (1.6 times in the total data set, range $=42.1$ to $69.2 \%$, Table 1). Again, the differences observed were not significant among sites for the PAR average (ANOVA, $\mathrm{p}>$ 0.05), but significant differences were found for leaf absorptance at the chlorophyll $a$ peak at $680 \mathrm{~nm}$ (ANOVA, p < 0.01).

Leaf absorptance showed a weak, though significant, relationship with total pigment density, both for the PAR average and for the chlorophyll a peak at $680 \mathrm{~nm}$ (Pearson correlation of log-log transformed data for the PAR average and for the $680 \mathrm{~nm}$ peak, were 0.68 and 0.67 respectively, $p<0.001$, Fig. 2). Leaf segments from 2 of the meadows (Sites 1 and 3) showed lower absorptance values relative to their pigment content (Fig. 2a,b). Those meadows also showed the highest average in the specific leaf area (SLA) values (Table 1). No significant relationship between SLA and leaf absorptance was observed when comparing leaves photoacclimated to 6 different sites (Pearson correlation, $\mathrm{p}>0.05$ ). However, a significant and negative association between SLA and leaf absorptance was observed, when the variability displayed by these parameters was examined within the same meadow, along the leaf and among leaves of the same shoot $(r=-0.78, p<0.05, n=7$, Fig. 3a). Taking into account all of the variability (e.g. within and among meadows), and despite the large variability found within sites, significant negative association between SLA and leaf absorptance was still observed $(r=-0.79, p<0.001$, $\mathrm{n}=13$, Fig. 3b).

Table 1. Thalassia testudinum. Mean $\pm \mathrm{SE}$ of the variation in leaf absorptance, chlorophyll $(a+b)$ density $\left(\mathrm{mg} \mathrm{m}^{-2}\right)$ and Specific Leaf Area (SLA, $\mathrm{cm}^{2} \mathrm{~g} \mathrm{dw}^{-1}$ ) among the 8 meadows examined in the Mexican Caribbean. N: no. of observations

\begin{tabular}{|c|c|c|c|c|c|c|c|}
\hline \multirow[t]{3}{*}{ Site } & \multicolumn{3}{|c|}{ Absorptance (\%) } & \multicolumn{3}{|c|}{ Chlorophyll $(a+b)$ density $\left(\mathrm{mg} \mathrm{chl} \mathrm{m}{ }^{-2}\right)$} & \multirow{3}{*}{$\begin{array}{c}\text { SLA } \\
\text { Mean } \pm \text { SE }\end{array}$} \\
\hline & & PAR average & & Mean $\pm \mathrm{SE}$ & Range & $\mathrm{N}$ & \\
\hline & Mean $\pm \mathrm{SE}$ & Range & $\mathrm{N}$ & & & & \\
\hline (1) & $55.7 \pm 2.0$ & $(45.4-66.7)$ & $21 \times 4$ & $68.5 \pm 9.3$ & $(26.6-115.5)$ & $10 \times 4$ & $416.6 \pm 12 . \subseteq$ \\
\hline (2) & $63.6 \pm 1.5$ & $(57.2-67.2)$ & $12 \times 4$ & $146.4 \pm 29.1$ & $(29.7-267.7)$ & $9 \times 4$ & $266.2 \pm 13.2$ \\
\hline (3) & $52.6 \pm 3.0$ & $(42.1-63.9)$ & $9 \times 4$ & $109.9 \pm 21.9$ & $(24.8-210.8)$ & $6 \times 4$ & $301.1 \pm 6.0$ \\
\hline (4) & $60.7 \pm 1.7$ & $(54.8-65.7)$ & $8 \times 4$ & $106.2 \pm 21.2$ & $(19.6-171.1)$ & $6 \times 4$ & $235.3 \pm 14.3$ \\
\hline (5) & $60.0 \pm 0.9$ & $(57.4-62.5)$ & $7 \times 4$ & $107.3 \pm 15.8$ & $(64.7-150.6)$ & $6 \times 4$ & $223.1 \pm 12.6$ \\
\hline (6) & $53.7 \pm 2.0$ & $(46.6-59.6)$ & $6 \times 4$ & $53.5 \pm 9.1$ & $(23.1-87.4)$ & $5 \times 4$ & $189.2 \pm 6.5$ \\
\hline (7) & $59.5 \pm 0.9$ & $(57.0-62.1)$ & $5 \times 4$ & $86.3 \pm 11.9$ & $(47.3-133.3)$ & $5 \times 4$ & $210.5 \pm 28.7$ \\
\hline (8) & $65.5 \pm 1.7$ & $(56.6-69.2)$ & $7 \times 5$ & & nd & & $173.7 \pm 7.7$ \\
\hline
\end{tabular}




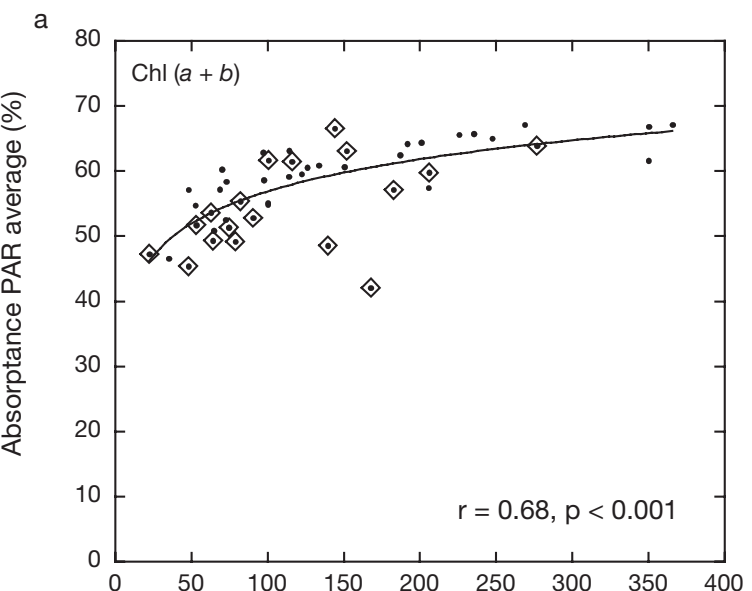

$$
\text { b }
$$

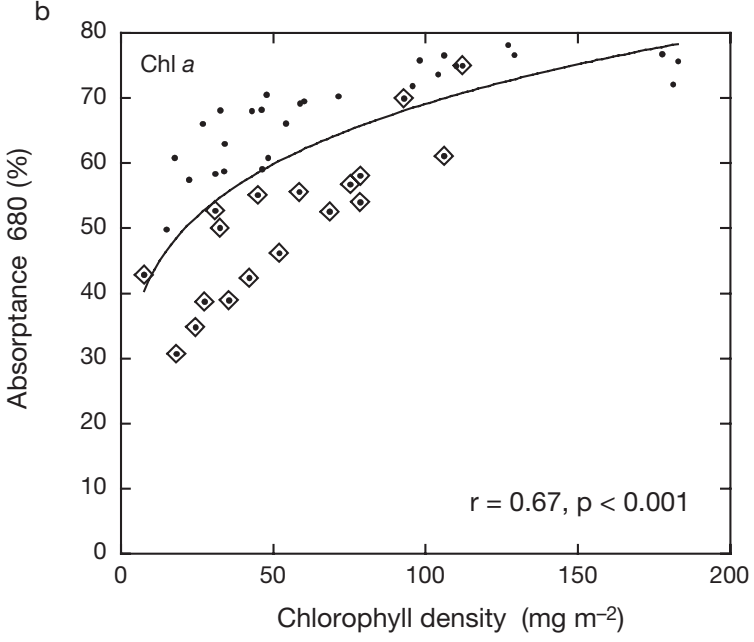

Fig. 2. Thalassia testudinum. (a) Variation in the PAR average leaf absorptance (\%) as a function of the variation in chlorophyll $(a+b)$ density $\left(\mathrm{mg} \mathrm{chl} \mathrm{m}^{-2}\right)$; (b) variation in leaf absorptance $(\%)$ at the chlorophyll a peak at $680 \mathrm{~nm}$ as a function of the variation in chlorophyll a density $\left(\mathrm{mg} \mathrm{chl} a \mathrm{~m}^{-2}\right)$. Diamonds refer to values from Sites 1 and 3

Examining the patterns of variation in leaf morphology and leaf photoacclimation shown by the shoot of a single Thalassia testudinum meadow (Site 5), it was observed that: (1) blades are thicker at the bases and reduce blade thickness progressively towards the leaf apex (Fig. 4a), (2) there was a significant progressive reduction in pigment content towards the leaf apex from a maximum located a few centimetres from the leaf meristem (Fig. 4a,b), and (3) blades tend to have higher SLA towards the leaf apex from a minimum located at the maximum pigment content (Fig. 4b). Consequently, there was a positive and highly significant association between leaf chlorophyll content and leaf thickness ( $\mathrm{r}=0.98$, $\mathrm{p}<$ 0.005, n = 5, Fig. 4a); a negative and highly significant association between chlorophyll content and SLA ( $\mathrm{r}=-0.97, \mathrm{p}<0.002, \mathrm{n}=6$, Fig. 4b); and a negative and highly significant allometric association
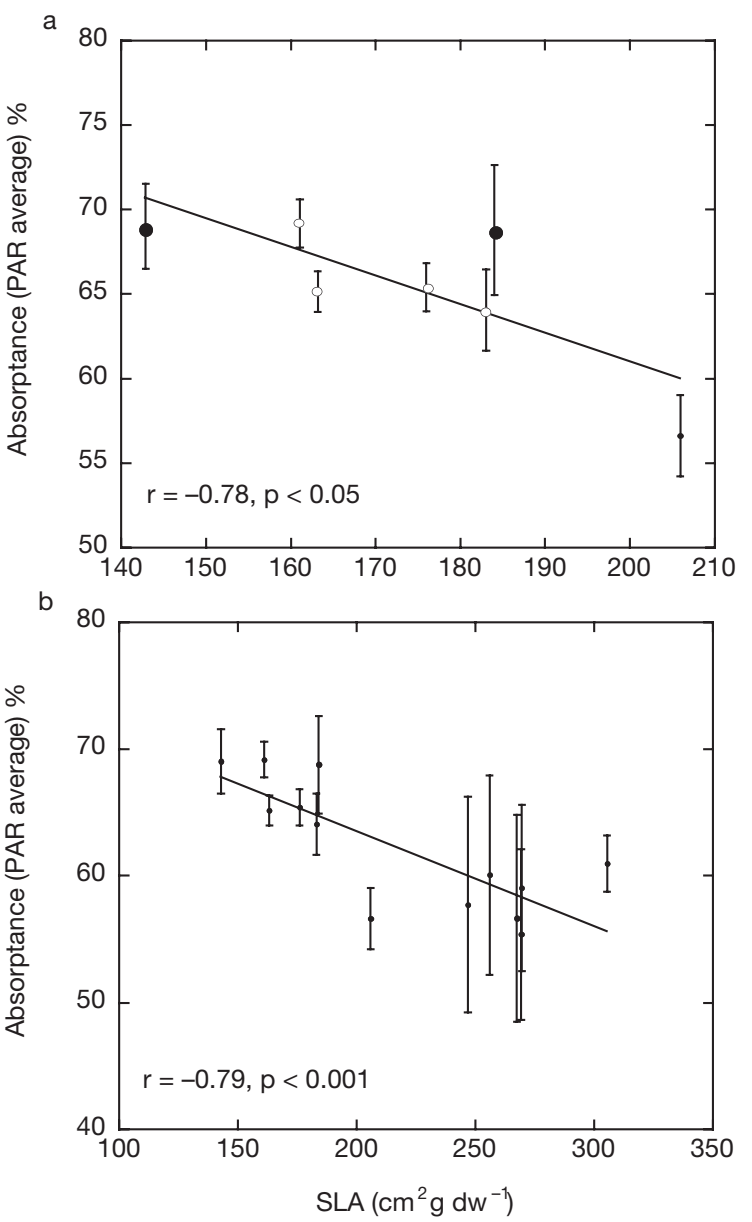

Fig. 3. Thalassia testudinum. Variation in the PAR average leaf absorptance (\%) as a function of the variation in the specific leaf area (SLA, $\mathrm{cm}^{2} \mathrm{~g} \mathrm{dw}^{-1}$ ). (a) Variability observed at Site 8 along the same leaf and among leaves of the same shoot. Small solid circles: values at the bases of the youngest leaf (Leaf \#1); small open circles: values at the bases, 5, 10 and $15 \mathrm{~cm}$ of Leaf \# 2; large solid circles: values at the bases and at $5 \mathrm{~cm}$ of Leaf \# 3;

(b) mean \pm SE of the intra- and inter-site variability

between SLA and leaf thickness $(\log -\log , r=-0.99, \mathrm{p}$ $<0.001, \mathrm{n}=5$ ) within the same meadow.

The analysis of the variation in pigment light absorption efficiency as a function of chlorophyll density showed a highly significant and negative association between the specific absorption coefficients $\left(\mathrm{a}^{*}\right)$ (for the PAR average, Fig. 5a; and for the chlorophyll a peak at 680 nm, Fig. 5b) and chlorophyll density. These associations were described by the following equations:

$$
\begin{gathered}
\mathrm{a}^{*}{ }_{\text {PAR }}=10^{0.47 \pm 0.06} \times \mathrm{chl}(a+b) \text { density }^{-0.80 \pm 0.03} \\
\left(\mathrm{R}^{2}=0.94, \mathrm{p}<0.0001, \mathrm{n}=47\right) \\
\mathrm{a}^{*}{ }_{680}=10^{0.64 \pm 0.1 \times \mathrm{chl} \text { a density }}{ }^{-0.65 \pm 0.06} \\
\left(\mathrm{R}^{2}=0.75, \mathrm{p}<0.0001, \mathrm{n}=47\right)
\end{gathered}
$$

This result indicates that chlorophyll efficiency for light absorption decreases non-linearly as pigment 


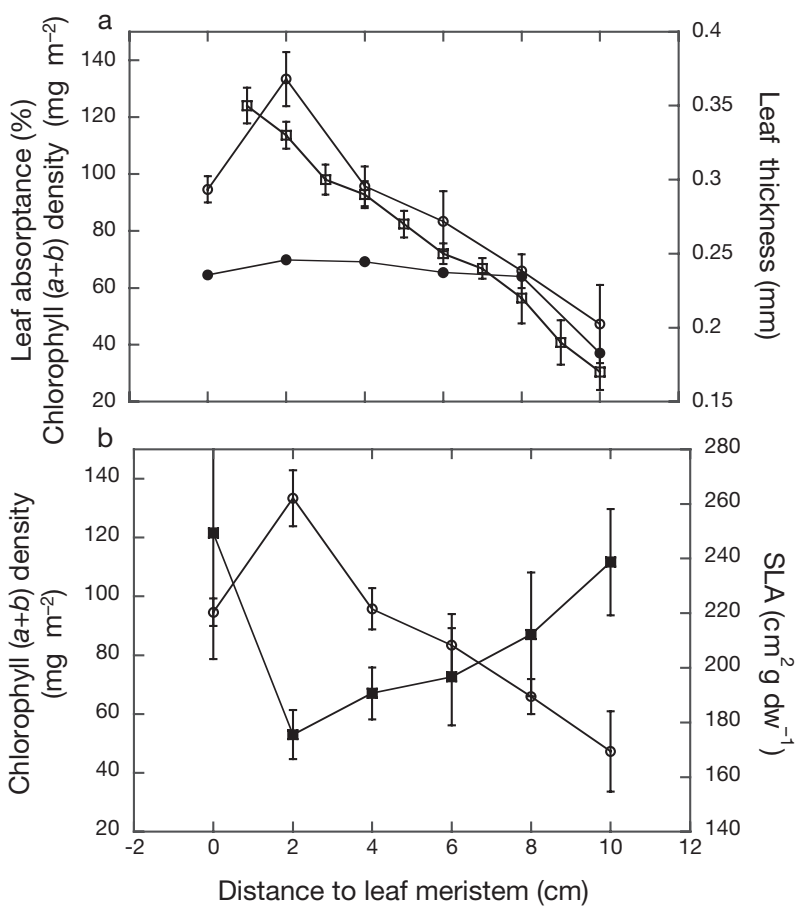

Fig. 4. Thalassia testudinum. Variation along the second youngest leaf in: (a) PAR average leaf absorptance (\%) (solid circles); chlorophyll $(a+b)$ density $\left(\mathrm{mg} \mathrm{chl} \mathrm{m}^{-2}\right)$ (open circles); and leaf thickness $(\mathrm{mm})$ (open squares); (b) chlorophyll $(a+b)$ density (mg chl m${ }^{-2}$ ) (open circles); and SLA $\left(\mathrm{cm}^{2} \mathrm{~g} \mathrm{dw}^{-1}\right)$ (solid squares). $x$-axis represents distance to leaf meristem $(\mathrm{cm})$

content per unit area increases (scaling coefficients are -0.83 for $\mathrm{a}^{*}$ PAR and -0.75 for $\mathrm{a}^{*}{ }_{680}$ after correction by RMA regression analysis; Niklas 1994).

Comparing the specific absorption values estimated for the chlorophyll a peak with those reported for Mentha aquatica (Enríquez \& Sand-Jensen 2003), chlorophyll a showed lower light absorption efficiency in Thalassia testudinum leaves than within $M$. aquatica leaves for most of the range examined (38\% on average, Fig. 5). Only the very low pigmented leaves of $T$. testudinum showed the highest chlorophyll a efficiency in the whole data set (Fig. 6). The average ${ }^{*}{ }_{680}$ value for $T$. testudinum $(0.025 \pm 0.002)$ was, however, 1.9 times higher than the average value for $M$. aquatica $(0.013 \pm 0.001)$ due to the 3-fold higher chlorophyll a content shown by M. aquatica leaves (Fig. 6).

Finally, the average $\mathrm{a}^{*}{ }_{680}$ value estimated in this study for Thalassia testudinum was compared to the values estimated for 4 temperate Mediterranean seagrasses: Posidonia oceanica, Cymodocea nodosa, Zostera noltii, Z. marina; and 6 tropical seagrass species from the Mexican Caribbean; T. testudinum, Halodule wrightii, Syringodium filiforme and the Philippines: Enhalus acoroides, Thalassia hemprichii, Halodule uninervis, Halophila ovalis and Syringodium isoetifolium. T. testudinum leaves showed the highest light
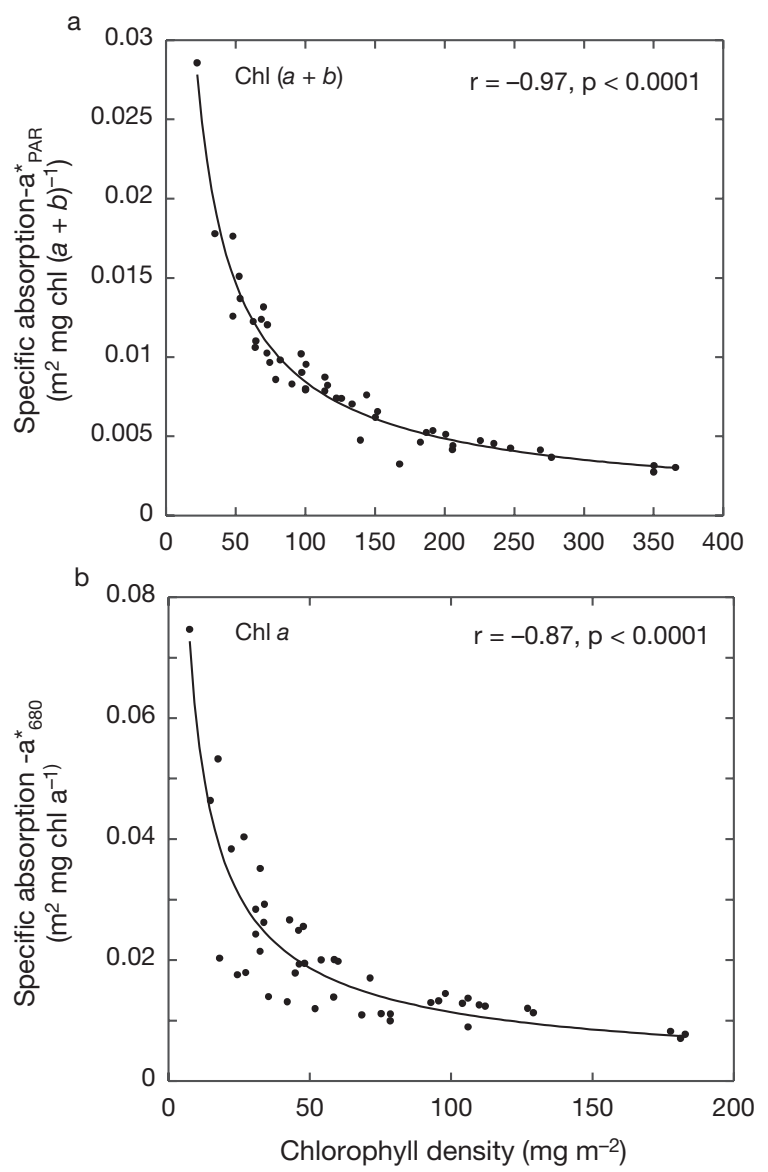

Fig. 5. Thalassia testudinum. Variation in the specific absorption coefficients $\left(a^{*}\right)$. (a) PAR average specific absorption coefficient $\left(\mathrm{a}^{*}{ }_{\text {PAR, }} \mathrm{m}^{2} \mathrm{mg}\right.$ pigm $\left.{ }^{-1}\right)$ as a function of chlorophyll $(a+b)$ density ( $\mathrm{mg} \mathrm{chl} \mathrm{m}^{-2}$ ); (b) specific absorption coefficient at the chlorophyll a peak at $680 \mathrm{~nm}\left(\mathrm{a}^{*}{ }_{680}, \mathrm{~m}^{2} \mathrm{mg} \mathrm{chl} \mathrm{a}^{-1}\right)$ as a function of the variation in chlorophyll a density $\left(\mathrm{mg} \mathrm{chl} a \mathrm{~m}^{-2}\right.$ )

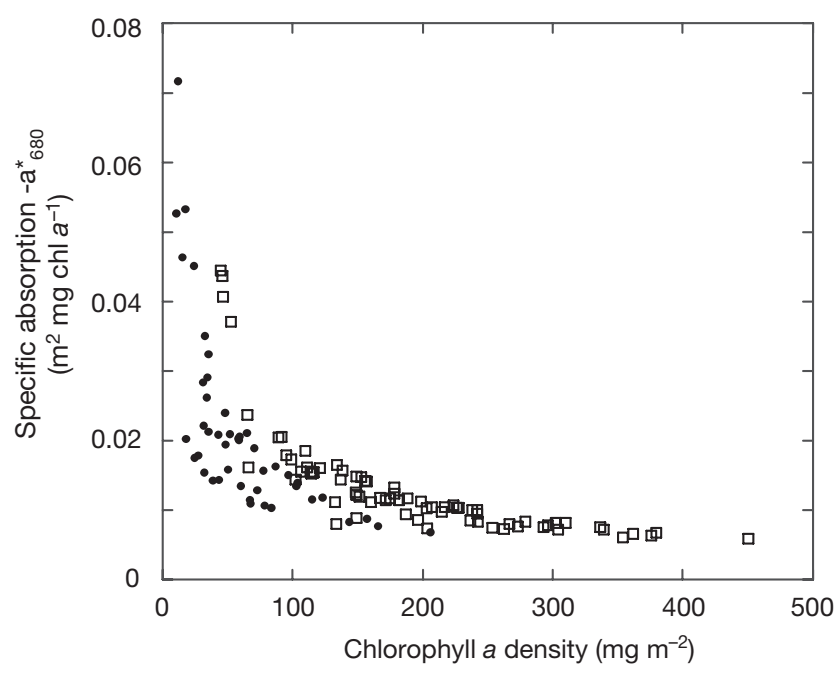

Fig. 6. Thalassia testudinum and Mentha aquatica. Variation in the specific absorption coefficients of $T$. testudinum (solid circles) and $M$. aquatica (open squares) at the chlorophyll $a$ peak at $680 \mathrm{~nm}\left(\mathrm{a}^{*}{ }_{680}, \mathrm{~m}^{2} \mathrm{mg} \mathrm{chl} \mathrm{a}^{-1}\right)$ as a function of the variation in chlorophyll $a$ density ( $\mathrm{mg} \mathrm{chl} \mathrm{a} \mathrm{m}^{-2}$ ) 
absorption efficiency among the 12 seagrass species examined, 2.4-fold higher than the lowest values estimated for $S$. isoetifolium, S. filiforme and P. oceanica (Fig. 7). Comparing all of the variability in $\mathrm{a}^{*}{ }_{680}$ considered in this study to the variation in chlorophyll a density, it was observed that the 4 temperate seagrass species showed, proportionally, the highest light absorption efficiency relative to their chlorophyll a content (Fig. 8).

\section{DISCUSSION}

The broad variability in pigment density and leaf absorptance in the leaves of Thalassia testudinum showed dissimilar variation, as 1 order of magnitude variation in pigment density was only reflected in a 1.5 -fold variation in leaf absorptance. The low efficiency of leaf pigments for enhancing light absorption within photosynthetic structures has been referred to as the package effect. This phenomenon was first empirically and theoretically studied for algal suspensions by Duysens (1956), and by Kirk (1975a,b, 1976) and Morel \& Bricaud (1981) for phytoplankton populations. The package effect has been described through (1) com-

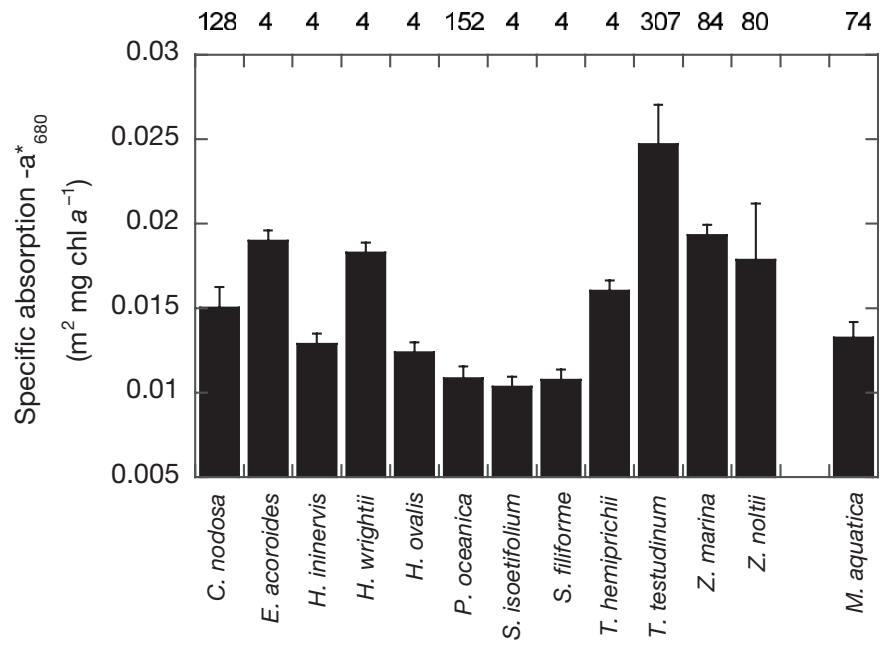

Fig. 7. Average + SE of the specific absorption coefficient at the chlorophyll $a$ peak at $680 \mathrm{~nm}\left(\mathrm{a}^{*}{ }_{680}, \mathrm{~m}^{2} \mathrm{mg} \mathrm{chl} \mathrm{a}^{-1}\right)$ for 4 temperate seagrasses (Cymodocea nodosa, Posidonia oceanica, Zostera marina and Z. noltii), 3 tropical seagrasses from the Mexican Caribbean (Halodule wrightii, Thalassia testudinum, Syringodium filiforme) and 5 tropical seagrasses from the Philippines (Enhalus acoroides, Halodule uninervis, Halophila ovalis, Thalassia hemprichii, Syringodium isoetifolium); and an amphibious freshwater macrophyte, Mentha aquatica. The number of spectroscopic determinations is shown at the top paring differences between in vivo spectra of intact and disrupted cells (Osborne \& Geider 1989, Kirk 1994), (2) estimating the photon path length ( $\beta$, sensu Rühle \& Wild 1979) or (3) describing the pattern of reduction in pigment light absorption efficiency as a function of pigment per unit of projected area (e.g. Geider \& Osborne 1992, Enríquez \& Sand-Jensen 2003). The analysis of the variation of the specific absorption coefficient was chosen here to quantify the magnitude of the package effect affecting the leaves of T. testudinum. According to the allometric function obtained, light absorption efficiency declines to the 0.83 power of pigment density. This value is similar to the allometric scaling factor reported for chlorophyll $a$ packaging into Mentha aquatica leaves (Enríquez \& Sand-Jensen 2003). Despite this similarity, T. testudinum leaves showed lower chlorophyll a-specific absorption coefficients than $M$. aquatica leaves for most of the range examined, with the exception of the very low pigmented leaves (Fig. 6). This result indicates that $T$. testudinum leaves are slightly less efficient for collecting light (38\% on average) than the bifacial leaves of $M$. aquatica (Fig. 6). Seagrass leaves do not have the specialized tubular palisade cells that facilitate the penetration of light into the leaf (Vogelmann \& Martin 1993), nor the spongy mesophyll that more efficiently increases the optical pathlength due to scattering at the interfaces between air spaces and cells (Terashima \& Saeki 1983). Yet, the larger chlorophyll a packaging in seagrass leaves may be explained by the fact that photosynthetic pigments are located 
within the thin epidermis. Nevertheless, the observation that temperate seagrass species showed 1.4 times higher absorption coefficients than $M$. aquatica leaves for similar chlorophyll a density (Fig. 8), implies that the absence of a specialized mesophyll in seagrass leaves and the appearance of a heterogeneous distribution of pigments has not necessarily led to a reduction in pigment light absorption efficiency.

Multiple scattering is the mechanism that allows dispersive structures to intensify light absorption (Butler \& Norris 1960). Increments in the optical path length resulting from multiple scattering within the photosynthetic structure may contribute to enhance light absorption and to counterbalance pigment selfshading. The finding that the allometric scaling factors are $>-1$, indicates that Thalassia testudinum leaves have the capacity to counterbalance pigment selfshading as highly pigmented leaves are proportionally more efficient than low pigmented leaves. Multiple scattering has been demonstrated to occur within bifacial leaves of terrestrial plants (Vogelmann \& Bjørn 1986), and its effect on the optical path length has been estimated for Mentha aquatica leaves ( $\beta$ - at the $680 \mathrm{~nm}$ chlorophyll a peak showed values $\beta>1$, Enríquez \& Sand-Jensen 2003). The ability of $M$. aquatica leaves to counterbalance pigment self-shading via multiple scattering relies on leaf morphology; leaf thickness directly contributes to enhance leaf absorptance, and SLA is strongly and positively associated with increments in leaf light absorption efficiency (Enríquez \& Sand-Jensen 2003). No relationship between leaf thickness nor any other leaf morphological descriptor and leaf light absorption has so far been described for seagrasses. Enríquez et al. (1992) did not find any significant effect of blade thickness on light absorption properties of seagrass leaves, contrary to the findings for phytoplankton (Morel \& Bricaud 1981, Agustí 1991a,b), macroalgal species (Ramus 1978, 1990) and a broad array of marine macrophytes (Enríquez et al. 1994). The comparison presented here does not directly address this question; however, a significant variation among sites in SLA (Table 1) with significant effect on leaf absorptance was observed (Table 1, Figs. 2 \& 3). This study also shows a strong colinearity between SLA, leaf thickness and pigment content (Fig. 4). This result, in addition to the finding that highly pigmented leaves are proportionally more efficient, suggests that leaf thickness and/or SLA may be directly associated with the variation in light absorption efficiency of leaf pigments. Thus, thicker leaves with lower SLA may reach higher values of leaf absorptance for similar pigment density. According to these relationships, seagrass leaves may have an opposite morphological response to light than the pattern described for land plants (Björkman 1981). Consider- ing that more than $80 \%$ of the leaf volume expansion associated with increases in leaf thickness occurs in the non-pigmented mesophyll surrounding the lacunar system, seagrass leaves will experience insignificant increases in pigment self-shading associated with increases in leaf thickness. Pigment efficiency for light absorption could, therefore, be improved by increasing the thickness of the unpigmented mesophyll. The presence of highly refractive structures such as air bubbles within the lacunar system or intracellular crystals within the epidermal cells (Dobbs et al. 2004) may also strongly improve light absorption efficiency of leaf pigments.

Pigment content and leaf absorptance are major descriptors of the photoacclimatory leaf response (sensu Falkowski \& La Roche 1991, Iglesias-Prieto \& Trench 1994). However, no significant differences among sites were observed despite the fact that leaves grew in meadows with depths between 0.5 and $4 \mathrm{~m}$. The largest variation was found along the same leaf (Table 1), whereas variation among leaves at different depths or environmental conditions was lower. The broad intra-leaf variation confirms the dominant role of the seagrass canopy in the regulation of the photoacclimatory leaf response of large seagrass species in a shallow and oligotrophic environment. It also highlights the importance of accounting for this variability in any experimental work that uses leaf pigment content as a descriptor of seagrass response, and calls for caution in the use of leaf absorptance as a constant value to estimate leaf photosynthetic rates such as ETR from fluorescence determinations (Genty et al. 1989).

Variation in leaf area per unit of leaf biomass, SLA, has also been considered of major importance to explain differences within and among species in the photoacclimatory leaf response (Björkman 1981, Enríquez et al. 1994, Markager \& Sand-Jensen 1994, Enríquez \& Sand-Jensen 2003). SLA is a common descriptor for terrestrial plant ecology, but has been rarely used by seagrass ecologists. Interspecific differences in SLA, but moreover, in the species-specific variability along a depth gradient have already been reported (Olesen et al. 2002). Significant association between SLA and leaf metabolism (maximum photosynthetic rates and dark respiration rates) have also been reported (Enríquez et al. 2004). The potential of SLA to monitor environmental changes in marine coastal areas may have been obscured by the large variability observed along seagrass leaves. The results of this comparison, however, suggest the potential use of SLA as a relevant descriptor in seagrass ecology.

The ecological consequences for seagrass survival of the variation of light absorption efficiency of leaf pigments have not been determined. Some authors have concluded that despite the small effect of 
increasing pigment content on leaf absorptance, light absorption efficiency of leaf biomass increases significantly with increasing pigment content per unit of leaf weight. This may have important ecological consequences for seagrass survival under light-limited conditions (Enríquez et al. 1992, 1994, Enríquez \& SandJensen 2003). Weight or mass-specific absorption coefficient $\left(\mathrm{a}_{\mathrm{W}}{ }^{*}, \mathrm{~cm}^{2} \mathrm{mg}\right.$ mass $\left.^{-1}\right)$ has been proposed as a descriptor of leaf biomass efficiency in absorbing light (Falkowski et al. 1985, Ramus 1990). As noted, weight-specific absorption is a mathematical construct, but it is a useful parameter for comparison, because it reflects the energy return per unit tissue produced (Ramus 1990, Enríquez et al. 1994, Enríquez \& Sand-Jensen 2003). Variation in the weight-specific absorption coefficient has been determined for Mentha aquatica leaves grown in 2 indoor experiments under different light and nutrient treatments (Enríquez \& Sand-Jensen 2003). According to these authors, the benefits of maximizing light absorption efficiency, both per unit of pigment and leaf weight, are not necessarily restricted to light-limited conditions; increases in light absorption efficiency under optimal growth conditions (i.e. higher nutrient availability) may also contribute to enhance plant fitness through increased plant relative growth rate. Weightspecific absorption coefficient values have been estimated for leaves of Posidonia oceanica and Cymodocea nodosa growing along a depth gradient (Olesen et al. 2002). Both species showed similar values except for the leaves grown in very deep meadows. Significant interspecific variation has been observed in a comparison of annual variation in leaf photosynthesis of 4 Mediterranean seagrasses (Enríquez et al. 2004). Among the 4 seagrasses examined (Posidonia oceanica, Cymodocea nodosa, Zostera marina and Z. noltii), Z. marina was the species that showed the highest pigment- and weight-specific absorption coefficient values. The possible dependence of leaf weight-specific absorption on the variation in SLA still needs to be examined, as well as the potential effect of this variation on leaf growth and seagrass survival under light-limited conditions.

In conclusion, chlorophyll a seems to be more 'packed' within Thalassia testudinum leaves than within the bifacial mesophyll of Mentha aquatica. However, this is not a general constraint of the specialized internal anatomy of seagrass leaves because temperate species have 1.4 times higher chlorophyll a efficiency than $M$. aquatica leaves with similar pigment density. Multiple scattering within the tissue explains the differential ability of leaves to counterbalance the package effect. The comparison made here does not directly address the effect of leaf morphology on the optical properties of seagrasses. Some conclusions can, however, be used as hypotheses to be examined in future work, such as the possible positive effect of leaf thickness and negative effect of SLA on the variation of light absorption efficiency of seagrass leaves. The ability to regulate light absorption efficiency per unit of leaf pigment or per unit of leaf biomass may be of primary importance for plant survival under low-light availability or under any environmental condition that requires maximizing plant growth. Further work is still necessary to fully understand the effect of leaf morphology on the optical properties of seagrass leaves and, as a consequence, on plant performance.

Acknowledgements. This work was supported by DGAPA (grant IN218599 to SE). N.I. Pantoja-Reyes is acknowledged for her field and laboratory assistance. I thank R. IglesiasPrieto for his helpful technical support in the determination of leaf reflectance, and A. Banaszak for providing access to the SpectraPro 300i spectrometer. The editorial assistance of P. Blanchon and A. Banaszak is also acknowledged. The experiments performed in this work comply with the current laws of Mexico.

\section{LITERATURE CITED}

Agustí S (1991a) Allometric scaling of light absorption and scattering by phytoplankton cells. Can J Fish Aquat Sci 48:763-767

Agustí S (1991b) Light environment within dense algal populations: cell size influences on self-shading. J Plankton Res 13:863-871

Arber A (1920) Water plants. A study of aquatic angiosperms. Cambridge University Press, Cambridge

Björkman O (1981) Responses to different quantum flux densities. In: Pirson A, Zimmermann MH (eds) Physiological plant ecology I. Responses to the physical environment. Lange OL, Nobel PS, Osmond CB, Ziegler H (eds) Encyclopedia of plant physiology. Vol 12A. Springer-Verlag, Berlin, p 57-107

Butler WL, Norris KH (1960) The spectrophotometry of dense light-scattering material. Arch Biochem Biophys 87:31-40

Cummings ME, Zimmerman RC (2003) Light harvesting and the package effect in the seagrasses Thalassia testudinum Banks ex König and Zostera marina L.: optical constraints on photoacclimation. Aquat Bot 75:261-274

Den Hartog C (1970) The Sea-grasses of the world. North Holland, Amsterdam, p 275

Dennison WC (1990) Chlorophyll content. In: Phillips RC, McRoy P (eds) Seagrass research methods. UNESCO, Paris p 83-85

Dobbs FC, Zimmerman RC, Drake LA (2004) Occurrence of intracellular crystals in leaves of Thalassia testudinum. Aquat Bot 80:23-28

Dubinsky Z, Falkowski PG, Porter JW, Muscatine L (1984) Absorption and utilization of radiant energy by light- and shade-adapted colonies of the hermatypic coral Stylophora pistillata. Proc R Soc Lond 222:203-214

Dubinsky Z, Stambler N, Ben-Zion M, McCloskey LR, Muscatine L, Falkowski PG (1990) The effect of external nutrient resources on the optical properties and photosynthetic efficiency of Stylophora pistillata. Proc R Soc Lond 239:231-246

Duysens LNM (1956) The flattening of the absorption spectrum of suspensions, as compared to that of solutions. Biochim Biophys Acta 19:1-12 
Enríquez S, Sand-Jensen K (2003) Variation in light absorption properties of Mentha aquatica L. as a function of leaf form: implications for plant growth. Int J Plant Sci 164:125-136

Enríquez S, Agustí S, Duarte CM (1992) Light absorption by seagrass Posidonia oceanica leaves. Mar Ecol Prog Ser 86: 201-204

Enríquez S, Agustí S, Duarte CM (1994) Light absorption by marine macrophytes. Oecologia 98:121-129

Enríquez S, Merino M, Iglesias-Prieto R (2002) Variations in the photosynthetic performance along the leaves of the tropical seagrass Thalassia testudinum. Mar Biol 140: 891-900

Enríquez S, Marbà N, Cebrián J, Duarte CM (2004) Annual variation in leaf photosynthesis and leaf nutrient content in four Mediterranean seagrasses. Bot Mar 47: 295-306

Falkowski PG, La Roche J (1991) Acclimation to spectral irradiance in algae. J Phycol 27:8-14

Falkowski PG, Dubinsky Z, Wyman K (1985) Growth irradiance relationships in phytoplankton. Limnol Oceanogr 30: 311-321

Geider RJ, Osborne B (1992) Algal photosynthesis. Chapman \& Hall, New York

Genty B, Briantais JM, Baker NR (1989) The relationship between the quantum yield of photosynthetic electron transport and quenching of chlorophyll fluorescence. Biochem Biophys Acta 990:87-92

Haardt H, Maske H (1987) Specific in vivo absorption coefficient of chlorophyll $a$ at $675 \mathrm{~nm}$. Limnol Oceanogr 32: 608-619

Iglesias-Prieto R, Trench RK (1994) Acclimation and adaptation to irradiance in symbiotic dinoflagellates. I. Responses of the photosynthetic unit to changes in photon flux density. Mar Ecol Prog Ser 113:163-175

Kirk JTO (1975a) A theoretical analysis of the contribution of algal cells to the attenuation of light within natural waters. I. General treatment of suspensions of pigmented cells. New Phytol 75:11-20

Kirk JTO (1975b) A theoretical analysis of the contribution of algal cells to the attenuation of light within natural waters. II. Spherical cells. New Phytol 75:21-36

Kirk JTO (1976) A theoretical analysis of the contribution of algal cells to the attenuation of light within natural waters. III. Cylindrical and spheroidal cells. New Phytol 77: 341-358

Kirk JTO (1994) Light and photosynthesis in aquatic ecosystems, 2nd edn. Cambridge University Press, Cambridge

Kuo J, Den Hartog C (2000) Seagrasses: a profile of an ecological group. Biol Mar Mediterr 7:3-17

Larkum AWD, Roberts G, Kuo J, Strother S (1989) Gaseous movement in seagrasses. In: Larkum AWD, McComb AJ, Shepherd SA (eds) Biology of seagrasses. A treatise on the biology of seagrasses with special reference to the Australian region. Elsevier, Amsterdam, p 686-722

Lesser MP, Mazel C, Phinney D, Yentsch CS (2000) Light absorption and utilization by colonies of the congeneric hermatypic corals Montastraea faveolata and Montastraea cavernosa. Limnol Oceanogr 45:76-86

Lichtenthaler HK, Wellburn AR (1983) Determination of total carotenoids and chlorophyll $a$ and $b$ of leaf extracts in different solvents. Biochem Soc Trans 603:591-592

Major KM, Dunton KH (2000) Photosynthetic performance in Syringodium filiforme: seasonal variation in lightharvesting characteristics. Aquat Bot 68:249-264

Editorial responsibility: Kenneth Heck (Contributing Editor), Dauphin Island, Alabama, USA
Major KM, Dunton KH (2002) Variations in light-harvesting characteristics of the seagrass, Thalassia testudinum: evidence for photoacclimation. J Exp Mar Biol Ecol 275: 173-189

Markager S, Sand-Jensen K (1994) The physiology and ecology of light-growth relationship in macroalgae. Prog Physiol Res 10:209-211

Morel A, Bricaud A (1981) Theoretical results concerning light absorption in a discrete medium, and application to specific absorption of phytoplankton. Deep-Sea Res 28: 1375-1393

Morel A, Bricaud A (1986) Inherent optical properties of algal cells including picoplankton: theoretical and experimental results. Can Bull Fish Aquat Sci 214:521-529

Niklas KJ (1994) Plant allometry: the scaling of form and process. University of Chicago Press, Chicago, IL

Olesen B, Enríquez S, Duarte CM, Sand-Jensen K (2002) Depth-acclimation of photosynthesis, morphology and demography of Posidonia oceanica and Cymodocea nodosa in the Spanish Mediterranean Sea. Mar Ecol Prog Ser 236: 89-97

Osborne BA, Geider RJ (1989) Problems in the assessment of the package effect in five small phytoplankters. Mar Biol 100:151-159

Ramus J (1978) Seaweed anatomy and photosynthetic performance: the ecological significance of light guides, heterogeneous absorption and multiple scatter. J Phycol 14:352-362

Ramus J (1990) A form-function analysis of photon capture for seaweeds. In: Lindstrom SC, Gabrielsen PW (eds) 13th Int Seaweed Symp. Hydrobiologia 204/205:65-71

Rühle W, Wild A (1979) The intensification of absorbance changes in leaves by light-dispersion: differences between high-light and low-light leaves. Planta 146:551-557

Sculthorpe CD (1967) The biology of aquatic vascular plants. Arnold, London

Shibata K (1959) Spectrophotometry of translucence biological materials: opal glass transmission method. Methods Biochem Anal 7:77-109

Terashima I, Saeki T (1983) Light environment within a leaf. I. Optical properties of paradermal sections of Camellia leaves with special reference to differences in the optical properties of palisade and spongy tissues. Plant Cell Physiol 24:1493-1501

Tomilson PB (1980) Leaf morphology and anatomy in seagrasses. In: Phillips R, McRoy C (eds) Handbook of seagrass biology: an ecosystem perspective. Garland Press, New York, p 7-28

Tomilson PB (1982) Anatomy of the monocotyledons. VII. Helobiae (Alismatidae). Clarendon Press, Oxford

Tyerman SD (1989) Solute and water relations of seagrasses. In: Larkum AWD, McComb AJ, Shepherd SA (eds) Biology of seagrasses. A treatise on the biology of seagrasses with special reference to the Australian region. Elsevier, Amsterdam, p 723-759

Vogelmann TC, Bjørn LO (1986) Measurement of light gradients and spectral regime in plant tissue with a fiber optic probe. Physiol Plant 60:363-368

Vogelmann TC, Martin G (1993) The functional significance of palisade tissue: penetration of directional vs. diffuse light. Plant Cell Environ 16:65-72

Wyman KD, Dubinsky Z, Porter JW, Falkowski PG (1987) Light absorption and utilization among hermatypic corals: a study in Jamaica, West Indies. Mar Biol 96:283-292

Submitted: March 19, 2004; Accepted: November 5, 2004

Proofs received from author(s): March 9, 2005 